\title{
GROUND DISPLACEMENT TRENDS IN AN URBAN ENVIRONMENT USING MULTI-TEMPORAL INSAR ANALYSIS AND TWO DECADES OF MULTI-SENSOR SATELLITE-BASED SAR IMAGERY
}

\author{
Iuliana Armaş $^{(1)}$, Marius Necşoiu ${ }^{(2)}$, Diana Aldea Mendes ${ }^{(3)}$, Mihaela Gheorghe ${ }^{(4)}$, Diana Gheorghe ${ }^{(1)}$ \\ ${ }^{(1)}$ University of Bucharest, Faculty of Geography, Department of Geomorphology-Pedology-Geomatics, \\ NicolaeBalcescu 1, Sector 1, 010041, Bucharest,Romania, Email:iulia_armas@geo.unibuc.ro \\ ${ }^{(2)}$ Geosciences and Engineering Division, Southwest Research Institute ${ }^{\circledR}, 6220$ Culebra Rd, San Antonio, TX, 78238, \\ United States of America, Email:mnecsoiu@swri.org \\ ${ }^{(3)}$ ISCTE-IUL, Department of QuantitativeMethods, Aceiro das Bicicletas, CCI 24021, Palhota, 2950-120 Palmela, \\ Lisbon, Portugal, Email: diana.mendes@iscte.pt \\ ${ }^{(4)}$ Technical University of Civil Engineering of Bucharest, Faculty of Geodesy, Bucharest, Romania, Email: \\ mihaelagheorghe10@gmail.com
}

\begin{abstract}
This exploratory research used three sets of single polarized synthetic aperture radar (SAR) satellite data and a multi-temporal radar interferometry (InSAR) methodology to determine the spatial evolution and ground displacement trends of several industrial parks located in the metropolitan area of Bucharest, Romania. From 70candidate areas, 20 large industrial parks were selected for analysis and interpretation. InSAR analysis used SAR data acquired between 1992 and 2014 by ERS-1/-2, ENVISAT, and TerraSAR-X satellites. Ground movement patterns identified before and after 2000 were linked to groundwater table investigations based on 25 water wells, located on or in the proximity of these areas. The analysis revealed an initial subsidence or no change in uplift areas before 2000, followed by a return to zonal movement. This trend may also be related to the shutting down of industries that consumed large amounts of water, which increased deep groundwater pressure. Only one continuous subsidence trend was identified for an industrial area located south of the city, an area which continues to be active over time. Ongoing researchis focused on using traditional geological andgeomorphologic investigations, as well as comparisons with fieldGlobal Navigation Satellite System (GNSS) data.
\end{abstract}

\section{INTRODUCTION}

Several recent studies are assessing ground instabilities in urban areas using conventional radar interferometry (InSAR) [e.g., 1-3] and multitemporal InSAR [e.g., 49]techniques. InSAR techniques have also been used to study the Bucharestmetropolitan area specificallyto detect and monitor ground displacement [e.g., 10-13] and derive new digital elevation models (DEMs) [1415].In this study (Fig. 1), we used Persistent ScatterersInterferometry (PS InSAR) to estimate the displacement trends over industrial park areas before and after 2000, when important water-consuming industries were shut down. From 70initial candidate areas,the largest 20 became the focus of this research. The observed displacement patterns were also analyzed in relation to the groundwater extraction geological strata.

Unlike conventional InSAR, PS InSAR uses the phase information of temporally coherent individual point scatterers to determine the time dependent ground displacements. The persistentscatterers (PS) are usually represented by objects with a high reflectance that remains constant in time, like buildings, dams, pipes, highways or rocks that are oriented in the sensor's line of sight (LOS) direction. Because the PS InSAR provides time series of displacement for individual scatterers, the technique can be limiting in terms of PS density. However, if enough point scatterers are detected, the technique offers the advantage of enhancing spatial resolution of deformation maps, which can be helpful for observing displacement patterns in detail.

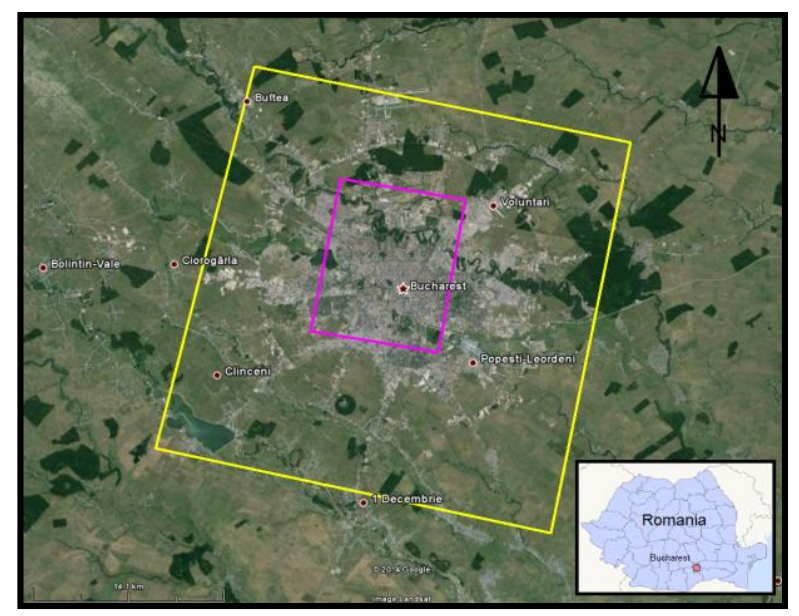

Figure 1. Outline of SAR data used in this study; magenta represents the extent ofTerraSAR-X and yellow represents ERS-1/2 and ENVISAT data. (Background image: (C) 2014 Google) 


\section{DATA AND METHOD}

PS InSAR analysis has been applied to76SARimages acquired byEuropean Space Agency (ESA) ERS -1/-2 and ENVISAT satellites and by the German Aerospace Centre (DLR) TerraSAR-X (TSX) satellite. The historical satellite data consisted of 28 ERS-1/-2 images, acquired between 1992 and 1999, and 24 ENVISAT images, acquired between 2003 and 2010. Twenty-four high resolution images were recently acquired by the TSX satellite between 2011 and 2014.These images were selected from a larger pool of SAR images, eliminating those acquired under poor weather conditions (i.e., snowfall, snow groundcover, rain, thunderstorms, and overcast skies). Datasets with large perpendicular baselines were also eliminated especially when associated with atmospheric conditions as previously described.Master files were defined for each stack of SAR datasets (i.e., ERS, ENVISAT and TSX)based on estimates of the expected measurement precision. Six one-arc-second X-band DEM products [16] covering Bucharest and the surrounding area were downloaded via DLR's EOWEB interface and mosaicked into one DEM product. The following InSAR products were generated:

- Mean displacement velocity

- Displacement history, which consists of the displacement magnitude for each input file with respect to the reference acquisition

- Measurement precision, for both mean displacement velocity and height

- Coherence

- Height correction with respect to the input DEM

- Total displacement

Finally,we calculated the mean deformation rates in each time period for 20 important industrial parks. A post-processing analysis of each time series was performed through manual recognition and classification of the behaviors of each industrial area. The resultsanalysis considered the geomorphologic aspects ofthe terrain, evolution of the groundwater levels, water needsovertime, and the history of industrial areas.

\section{RESULTS AND DISCUSSION}

ThePSInSAR techniqueapplied to each SAR dataset was capable of measuring very small deformations (e.g., 1 $\mathrm{mm}$ /year) allowing a synoptic view of Bucharest land deformations over 22 years. Over the urban and periurban areas,PS InSARanalysis returned more than 30,000 PS in the time interval 1992-2000 (ERS data) and more than 60,000 in 2003-2010 (ENVISAT data). Processing of TSX data identified even a higher density of PS (i.e., 600,000 points).The InSAR analysis reveals (a) an estimated mean displacement rate rangingbetween -8 up to $2 \mathrm{~mm} / \mathrm{yr}$ (estimated PS velocity precisions being $\sim 0.3 \mathrm{~mm} / \mathrm{yr}$ for ERS and ENVISAT and $\sim 0.2 \mathrm{~mm} / \mathrm{yr}$ for TSX InSAR products)and (b)that two trends seem to characterize the dynamics of these industrial parks. These trends can be described as(a) a normal (i.e., no change or the expected subsidencepattern between 1992 and 1999, and uplift after 2003)and (b) a continuous uplifting pattern, with a period of stability before 1999 and a more accelerated rising trend after 2003 (Fig. 2). An exception to those trends (i.e., continuous subsidence) was identified for an industrial area, located in the south of the city.

\subsection{Rising of the groundwater table}

Geotechnical studies conducted in different areas of the city revealed that the hydrostatic level underwentchanges during the last 80 years, rising generally at least a few meters $[17,18]$, as a result of obstruction of the groundwater's drainage toward the Colentina and Dâmboviţa rivers. The obstruction seems to have been almost inevitable in a city that has seen continuous expansion in the last decades. For example, the construction of the subway underground galleries, which started in 1975, could represent the first important obstacle towater drainage.In addition, after the fall of communism in 1989, and especially after 2005, numerous buildings with 2 to 5 underground stories were built, which could represent an additional obstruction for natural water drainage. Meanwhile, the water and sewer networks received almost no improvements over time and served a growing number of consumers. The leakage of water caused by poor sewer networks represented yet another reason for increases of the piezometric level.

In addition to the groundwater's drainage obstruction, which affects mainly the water table aquifers, recent groundwater table investigations of 25 water wells located on or near the areas of interest indicate an increase in deep groundwater pressures mainly after 2000 [17]. Reference [19] confirmed that the annual water needs of Romania decreased from 20.5 billion cubic meters of water in 1990 to 8.45 cubic meters in 2010, having as distinct time intervals 1990-2000 and 2001-2010. The same trend is available for Bucharest, where industry accounts for approximately $67 \%$ ofthe total wateruse, derivedmainly fromextractions of confined groundwater reserves from the Frăteşti geologic strata. Thesestrata represent an alternation of alluvial gravel and sand layers of inferior Pleistocene age, having a total thickness that varies from south tonorth between $100 \mathrm{~m}$ and $180 \mathrm{~m}$. The aquifers of the Frăţeşti geological strata have been divided into three geological beds: A (the superior bed, the most exploited during the communist regime), $\mathrm{B}$ (the medium bed), and $\mathrm{C}$ (the inferior bed). Therefore, the closing of many factories in the last two decades might have had an important influence on the groundwater recharge. 


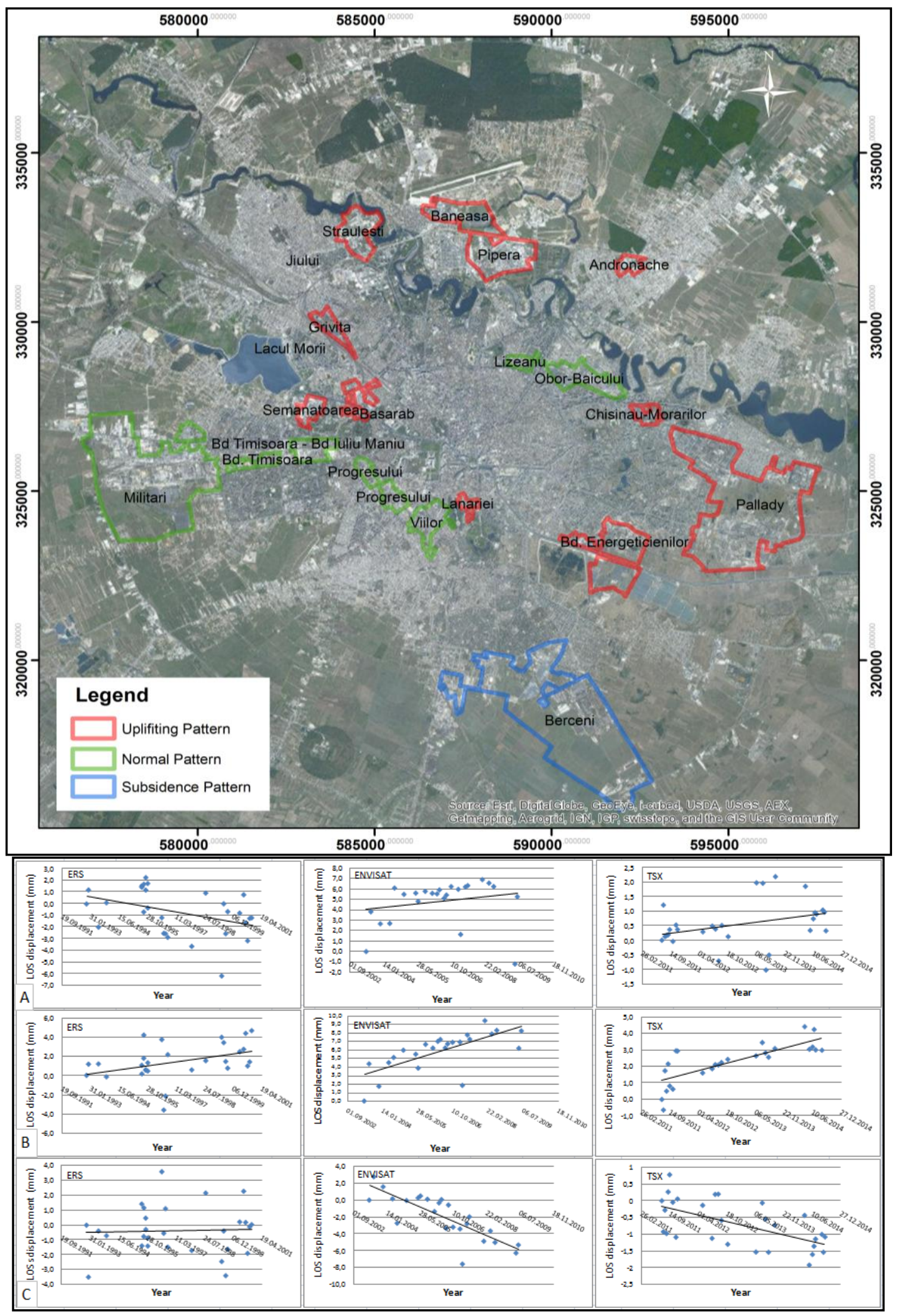

Figure 2. Location of industrial areas that display different displacement trends.a) normal or expected (e.g., Militari); b) a continuous pattern of uplift (e.g.,Basarab); c) subsidence (e.g.,Berceni) 


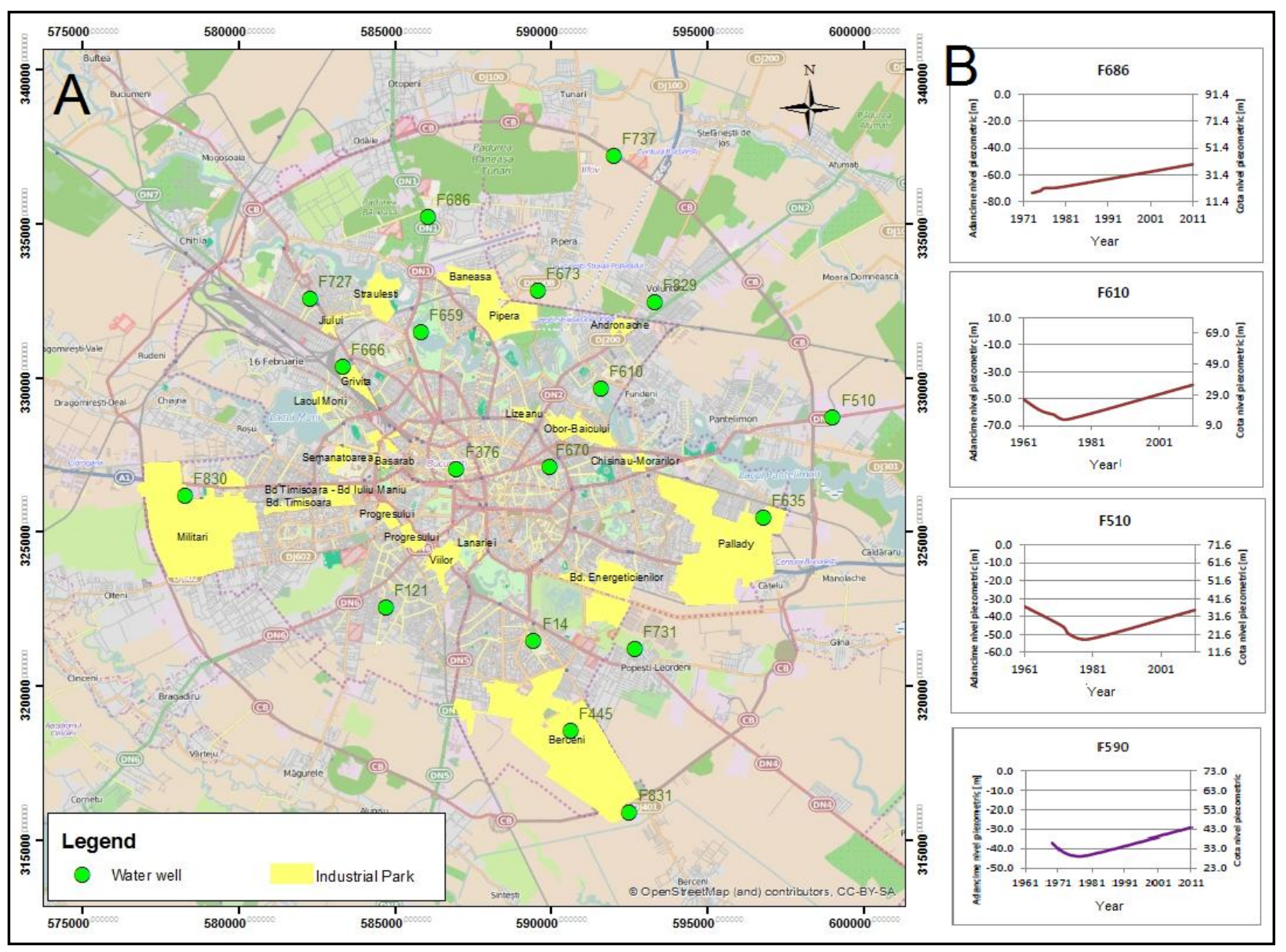

Figure 3.a) Water wells used in analysis for groundwater table recharge identification and industrial areas in Bucharest; b) Evolution of the groundwater level at the location of water wells (Source: [18])

In fact, in only 15 years (i.e., from 1990 to2005),industrialwater needshave been reduced by half[18].

Reference [18] compared results of 25 water wells drilledto explore mainly the A level of the Frăţeşti strata.Several water wells were located on industrial areas or in their vicinity (Fig. 3a). Fig. 3b shows the rising hydrostatic level of groundwater from the Frăteşti strata, bed A, between 1971 and 2011.

\subsection{Trends of the industrial areas}

Several studies [e.g., 5, 6, and 9] documenteda direct relationship between groundwater extraction and subsidence in urban areas.Industrial parks are generally located toward the periphery of the city, and Bucharest is no exception. In fact, by looking at the location of these areas depicted on historical maps, we can identify Bucharest's development stages. During the communist era, many of the studied industrial parks were established outside the city limits. As the town developed, some of these industrial zones were slowly incorporated in the city limits, with many changing their functionover time.The industrial parks belonged to heavy industries (e.g., machinery, textile, chemical, and construction material) and werelarge water consumers. The necessary water was extracted from the deep confined groundwater of the Frăteşti strata [18, 20].After 2000, many of these parks were closed andreplaced by new developments.

\subsection{The "normal"trend}

The first trend, called the "normal" or "expected" pattern, shows subsidence in 1992-1999 and uplift after 2003. This pattern is represented by 8 industrial parks (Fig. 3A). Some of them, such as Timisoara, Iuliu Maniu, Militari, Progresului and Obor-Baicului, are found in larger zones affected by subsidence, while Viilor and Lizeanu are found in zones that display a slow upward trend.Thesetwo industrial areas are characterized by mean annual displacement rates different from theirsurroundings. Specifically, before 1999, Viilor was very slowlysubsiding, with a mean velocity value of -0.72 $\mathrm{mm} / \mathrm{yr}$, while its 300-meter surroundings werevery 
slowly rising at a rate of $0.60 \mathrm{~mm} / \mathrm{yr}$. Thispositive trend was maintained after 2003 at $0.77 \mathrm{~mm} / \mathrm{yr}$, while the surrounding areawas ascending at a rate of $0.50 \mathrm{~mm} / \mathrm{yr}$. It was also noted that the estimated annual mean displacementof the surroundings is smaller than that of the industrial areas.For example, the Obor-Baicului industrial areahad an estimated displacement of $1.46 \mathrm{~mm}$ before 1999 and $3.15 \mathrm{~mm}$ after 2003, while the surrounding area wasrelatively stable (i.e., $-0.46 \mathrm{~mm}$ until 1999 and $0.13 \mathrm{~mm}$ after 2003). Results also revealed consistency in the trends detected by ENVISAT and TSX after 2000, even if TSX-based InSAR results were able to detect finer movements of the areas.

\subsection{The "uplifting"trend}

The continuous uplifting pattern was noticed on 11industrial areas located between the Dâmboviţa and Colentina rivers, on the colluvio-proluvialglacis in the Dâmboviţa River's floodplain, and on the left bank of the Colentina River (Fig. 3). The uplifting tendency of these areas isalso reflected by theQuaternary evolution of Dâmboviţa valley, which was constantly sliding toward thesouthwest, formingterrace levels on its left bank.The uplift trend might have a tectonic cause;this aspect will be the subject of a follow-up analysis.Although the industrial areas are found on generallyuplifting surroundings and display a similar displacement trend, their displacement variations are comparable to the surroundings before 1999 and significantly higher after 2000.Except forLânărieiindustrial park, which shows an uplifting trend of $1 \mathrm{~mm} /$ year before 1999, the other 10 industrial areas displayed velocities between $0.2 \mathrm{~mm} / \mathrm{yrand} 0.4$ $\mathrm{mm} /$ year on average, indicative ofa relatively stable ground.

As was also noted in 3.3, TSX-based resultsfrom recent years confirm the trendnoted in the ENVISAT-based results for 8 out of 11 industrial areas.However, the 2011-2014 rising trend detected by TSX data is more accelerated than that before 2010 , with a velocity of $1.02 \mathrm{~mm} / \mathrm{yr}$, in comparison to $0.6 \mathrm{~mm} / \mathrm{yr}$ before 2010 . The magnitude of the displacements resulted from the TSX data beingcomparable to the ENVISAT data (i.e., $3.25-\mathrm{mm}$ annual displacement versus $4.18 \mathrm{~mm}$ ).

Two out of 11industrial areas that displayed a slow rising trend in 1992-1999, witha slight subsidencepattern toward 2010, continued a subsidencepattern as shown inPS TSX-basedresults after 2011. These two industrial areas are Bd. Energeticienilor and Pallady. We tried to explain the trend anomalies of the two industrial areas by looking into the history of the areas after 2000 .

By consulting historic imagery from Google Earth ${ }^{\mathrm{TM}}$, we could identify new features that were built in the
Energeticienilor industrial area in the last 12 years. Changes observed using imagery have been also confirmed by historic records regarding the functionality of the industry in that area. For example,CET SudBucureşti, a steam power plant thatstarted operatingin 1965, had its operationspartially halted in 1975. Its full activity resumed in 2000 after its rehabilitation in 2000, which caused a possible increase in local water extraction. In addition, the area adjacent to the industrial park had a dramatic increase in the number of residential buildings, which may have further increasedthe water consumption in the areaand also generateda soil compaction process.

After 2003, the ENVISAT data, and after 2011, the TSX data, show a steep decrease in mean displacement values of the Pallady industrial area. Neither the visual assessment of the historic development of the buildings of the industrial area nor the history of industrial activity could explain the clear downward tendency of the industrial area shown in ENVISAT and TSX-based results. The only water-consuming industry that is still active in the area is a paint factory, which has been functioning for the last 50 years.

Becausethe surrounding area displays the same trend as the industrial area, one possible reason for the noticed pattern is the presence of a former water course, now buried, that could present an underground active drainage system toward Dâmboviţa.

\subsection{A trend exception}

From the 20 analyzed industrial areas, only one located in the southeast part of the city (i.e., Berceni industrial area) displayed a continuous subsidence trend. Before year 2000, InSAR results point to a relative stable area. However, after 2000, negative velocity rates increased to $-2.08 \mathrm{~mm} /$ yrbefore 2010 and slowly decreased, but kept the trend to $-0.35 \mathrm{~mm} / \mathrm{yr}$ after 2011 (Fig. 3C). Over this period of time,factories in Berceni continued to operate. At least one heavy machinery factory, IMGB, has been active for over 50 years. In addition, starting in 2007, at least 4 other heavy machinery corporations began activitiesin this area. PS associated with the location of these new businesses show higher negative displacements(e.g., $-15 \mathrm{~mm}$ in 2008) and large negative mean annual velocities of -2.5 to $-4 \mathrm{~mm} / \mathrm{yr}$. In addition to these activities, the Berceni industrial area is surrounded by residential areas, which sawa dramatic expansion after 2000, therefore causinga drop in pore pressure (Fig. 4a, 4b). Both of these factors could contribute to increased water needs, as reflected in the trends identified by this analysis. 


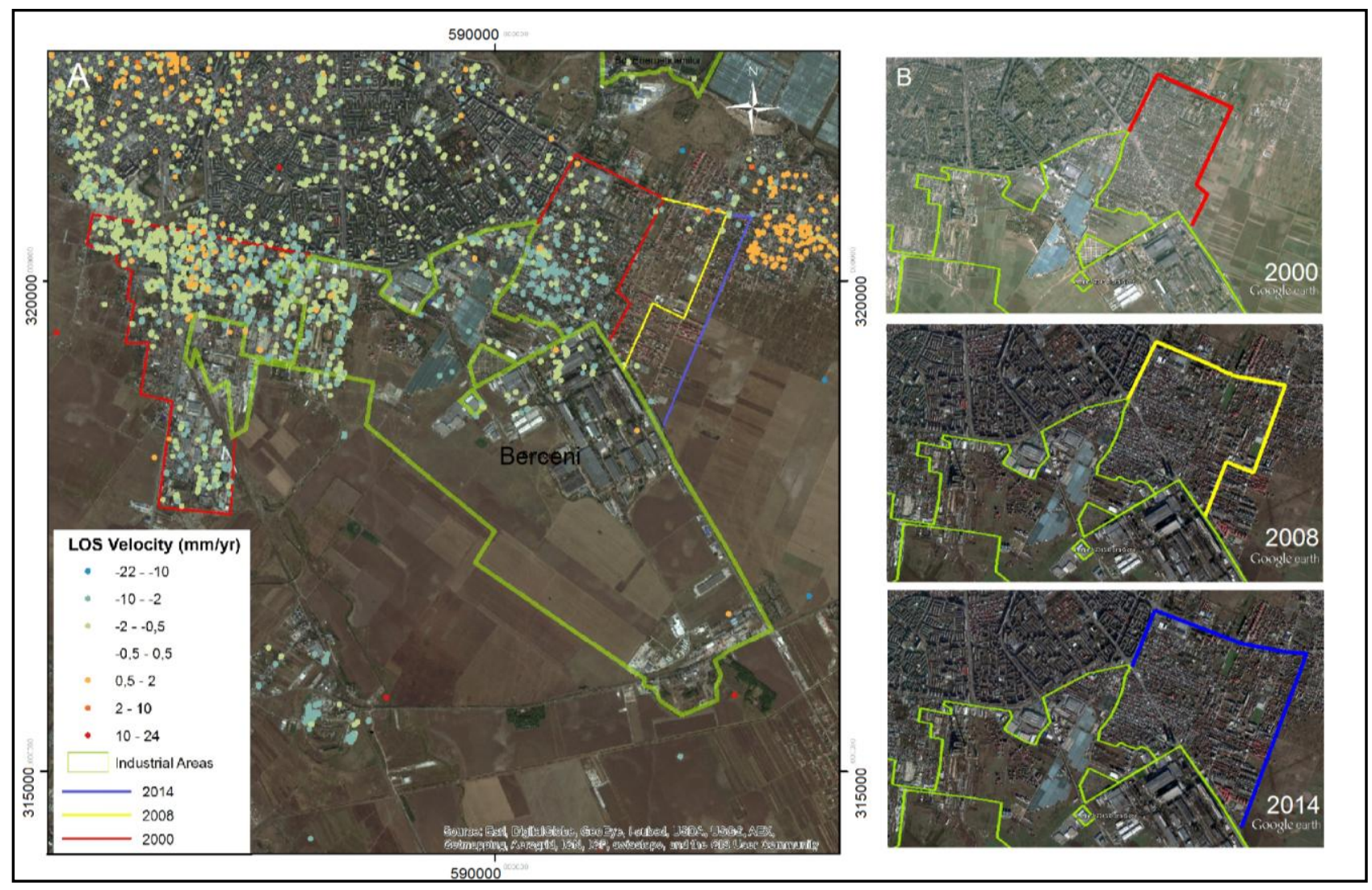

Figure 4. Evolution of the built-up area in Berceni in the last 14 years; a)Expansion of the residential area found in the vicinity of the Berceni industrial area. Red line delimitates the built-up area in 2000, yellow line in 2008, and blue line in 2014; b)Increased density of residential buildings as depicted in 2000, 2008, and 2014.(Background images: () 2014 Google)

\section{CONCLUSION}

Estimated displacement rates over the last 24 years indicate that the surface of the Bucharest urban area is relativelystable. Although the estimated mean velocities are very small, the estimated patterns over the industrial areas are slightly distinct from theirsurroundings. Overall, the analysis shows that immediately following the communist era, an eracharacterized by intense exploitation of the groundwater resources, slow uplifting occurred overthese areas. This may be the result of closing the main industrial consumers, which decreased the water needs, followed by a comeback to the zonal dynamic pattern.An exception was the continuous subsidence trend noted over the Berceni industrial area, one of the few industrial parks that not only continued to exist over time, but becameeven more active in the last decade.

\section{Acknowledgments:}

This research was financed by grant 285/2011 of the Romanian National Authority for Scientific Research and grant 78/29.11.2013 with the Romanian Space
Agency. ERS-1/-2 and ENVISAT data were provided by ESA Category-1 Proposal no. 12793 entitled "Patterns of Change in Ground Subsidence in Urban Areas Based on Historical Maps and Satellite Data. Case Study: Bucharest, Romania." TSX data were provided via DLR Proposal LAN 1444 entitled "Ground Subsidence in Bucharest, Romaniabased on Historical and Recent Data."

\section{REFERENCES}

1. Weydahl, D.J. (2001). Analysis of ERS SAR coherence images acquired over vegetated areas and urban features. International Journal of Remote Sensing, 22(14), pp. 2,811-2,830.

2. Grey, W.M.F., Luckmana, A.J. \& Holland, D. (2004). Mapping urban change in the UK using satellite radar interferometry. Remote Sensing of Environment, 87, pp. 16-22.

3. Karila, K., Karjalainen, M. \& Hyyppä, J. (2005). Detection of Urban land subsidence in the city of Turku in Finland using differential SAR interferometry. ESA SP 572, pp. 929-932. 
4. Ferretti, A., Prati, C. \& Rocca, F. (2000). Non-linear subsidence rate estimation using permanent scatterers in differential SAR interferometry. IEEE Trans. Geoscience and Remote Sensing, 38(5), 2202-2212.

5. Worawattanamateekul, J., Hoffman, J., Adam, N. \& Kampes, B. (2003). Urban deformation monitoring in BANGKOK metropolitan (Thailand) using permanent scatterer and differential interferometry techniques. Proceedings of FRINGE 2003 Workshop, ESA/ESRIN, Frascati, Italy.

6. Kim, J. S., Kim, D. J., Kim, S. W., Won, J. S. \&Moon, W. M. (2007). Monitoring of urban land surface subsidence using PSInSAR. Geosciences Journal.11, 59-73.

7. Herrera, G., Tomas, R., Lopez-Sanchez, J.M., Delgado, J., Vicente, F., Mulas, J., Cooksley, G., Sánchez, M., Duro, J., Arnaud, A., Blanco, P., Duque, J., Mallorqui, J.J., Vega-Panizo, De la R., \&Monserrat, O. (2009). Validation and comparison of advanced differential interferometry techniques: Murcia metropolitan area case study. ISPRS Journal of Photogrammetry and RS, 64, 501-512.

8. Crosetto, M., Monserrat, O., \&Herrera, G. (2010). Urban applications of persistent scatterer interferometry in radar remote sensing of urban areas, Soergel U. (Ed), Remote Sensing and Digital Image Processing, 15(2), 33-248 http://rd.springer.com/chapter/10.1007/978-90481-3751-0_10\#

9. Ng, A. H.-M., Ge, L., Li, X. \& Zhang, K. (2012). Monitoring ground deformation in Beijing, China with persistent scatterer SAR interferometry. Journal of Geodesy. 1-18.

10. Armaş, I. \& Necşoiu, M. (2011). Ground subsidence in Bucharest, Romania, based on historical and recent data, 3. TanDEM-X Science Team Meeting, DLR Oberpfaffenhofen, Germany.

11. Poncos, V., Serban, F., Teleaga, D., Ciocan, V., Sorin, M., Caranda, D., \&Raduca, V. (2012). Water induced geohazards measured with spaceborne interferometry techniques, $E G U$ General Assembly Conference Abstracts,14, p. 4,654 .

12. Necşoiu, M., Armaş, I., \&Gheorghe, D. (2013). Detecting ground deformation in Bucharest, Romania, using high-resolution multi-temporal InSAR and TerraSAR-X Data, 5. TerraSAR-X Science Team Meeting, DLR Oberpfaffenhofen, Germany.

13. Poncos, V., Patrascu, C., Teleaga, D., \&Datcu, M. (2013). Monitoring urban subsidence in Bucharest
City with TerraSAR-X, 5.TerraSAR-X Science Team Meeting, DLR Oberpfaffenhofen, Germany.

14. Poncos, V. \& Dana, I. (2008). Interferometric Generation of Digital Elevation Models for Urban Areas Using TerraSAR-X. 3. TerraSAR-X Science TeamMeetingDLR Oberpfaffenhofen, Germany.

15. Dana, I., Poncos, V., \&Teleaga, D. (2009). Comparative analysis of Insar digital surface models for test area Bucharest. FRINGE 19-23 September 2011, ESA, Frascati, Italy.

16. SRTM-X (2011). Elevation models from SRTM now available for download free of charge http://www.dlr.de/dlr/en/desktopdefault.aspx/tabid -10212/332_read-817/

17. Raduinea, N. (2014). Realizarea incintelor adanci in Bucuresti si posibile implicatii in viitor asupra apelor subterane. Revista Constructiilor. X(105), 44-46.

18.Ivan, M. (2012). Evaluarea condiţiilor hidrogeologice actuale ale sistemului acvifer Frăteşti în zona Municipiului Bucureşti, University of Bucharest, PhD thesis (unpublished), Bucharest, Romania.

19.The National Administration of Romanian Waters. (2012). Cerinta totala de apa in Romania a scazut la jumatate fata de anul 1990. Cea mai dramatica scadere se inregistreaza in sectorul agricol[Press release]. Revista Presei, pp 3-5.

20.Palcu, M., Melinte, M. C., Jurkiewicz, A., Witek, G. \&Rotaru, A. (2008).Inventariereapreliminară a structuriloracvifere din parteasudică a României. GEO-ECO-MARINA, Sstiințele Pământului, Cunoaştere şi Mediu 14(17), 7-16. 